\title{
Philosophical heroism and theological heroism
}

\section{George REMETE* Jean NEDELEA*}

Abstract: Heroism is the criterion of humanism in general. There is a philosophical vitality, meaning a non-Christian one and a Christian vitality. The non-Christian vitality gave and still gives exceptional samples of heroism. Therefore the Christian theologian must prove the specific and the value of Christian heroism and vitality. Generally, Christian heroism is identified with martyrdom. It is also extremely important to understand that there is heroism without martyrdom. Having in view that to be an authentic Christian means to be a hero every day, it is necessary to be aware of this necessity and possibility. If the martyrdom is the heroism of the red blood, the sacrificial goodwill is the heroism of the white blood.

Keywords: Philosophical, Christian heroism, martyrdom, vitality, red blood, white blood.

As a principle, the issue seems simple: being exactly the reason of living, ration promotes it implicitly. Nevertheless, in fact 'the promotion of life' and 'the vitalism' came to be understood very differently in various philosophical and

* PhD, Rev., Professor, Faculty of Orthodox Theology at "1 Decembrie 1918" University, Alba Iulia, Romania.

* PhD, Junior Lecturer, Faculty of Orthodox Theology "Justinian Patriarhul" at Bucharest University, Bucharest, Romania. 
theological conceptions and, especially, to represent an important difference between philosophy and theology.

\section{The complain of anti-vitalism against (christian) theology}

The problem of vitalism took the most severe and important form in the complaint that philosophy brings to theology (in general) and to the Christian one (in particular) that, by stating 'the afterlife' as an ultimate reality, it despises the world and the human being and sabotages life. Incomparable remains in this polemics the German philosopher Fr. Nietzsche. Even if he is led by a devouring fury, any honest thinker must recognize in his word the force of an exceptional logic. Probably no one has ever asked more ferociously and obliged stronger Christianity to answer about the relationship with the world and life. Nietzsche states that Christian religion is the biggest destroyer of the world and of life. He considers Christianity as 'the only great curse, the only wide internal corruption, the only large instinct of hate... the only shameful, immortal spot of humankind', which 'has made from every value a non-value, from every truth a lie, from every fairness a blackness of mind"2. It is not only about some ideas or statements of Christian theology assumed as wrong. Nietzsche believes that Christian religion is the conception that perfectly systematizes the hate against the world and life, that through it 'the centre of gravity of life is not in life but it is moved "beyond», in nothing... To live in such a way that there is no reason of living... '3. As the Christian religion maximized according to Nietzsche - the moving of life from here to beyond, for him the Christian theologian is "this denying, this libelous and poisonous through his job of life... the conscientious lawyer

${ }^{1}$ Fr. Nietzsche, The Antichrist, 62, Cluj, Apostrophe Library, 1996, p. 94.

${ }^{2}$ Ibid.

${ }^{3}$ Ibid., p. 58. 
of nothing and of denial'4. Almost all theologians consider these complaints, and especially Nietzsche's irrepressible fury, as being irrational and unworthy of any answer. But we believe that his polemics is as serious as it can be, worthy of the biggest interest and it is the best touchstone for the clarification of the Christian conception.

For Nietzsche, the clearest proof of the destruction of life by the Christianity is the type of human promoted: humble, submitted, weak, vile, totally opposed to ancient kind: noble, haughty, proud and bold. Nietzsche's philosophical and ancient instinct makes him feel, ingeniously, that indeed 'Christianity kept everything that is weak, vile, degenerate, it created an ideal through contradicting the instinct of conservation of powerful life ${ }^{5}$. Otherwise, it has to be observed that Nietzsche's vision on Christian man is not invented by him, but it's the reproduction of the pagan one. Ancient pagans saw the Christians in the same way: 'ignorant men, from the lowest mud, and easy gullible women ... withdrawn and running from light ... they despise the old temples, spitting against the gods ... they despise the governors and purple, they who are almost naked... they despise the current torments, but they fear the unsure future; they do not fear death, but they are afraid not to die after death; thus they create groundless fears and they are caressed by the thought of a future life'. 6 The antagonism between the ancient and the Christian model is thus anytime the antagonism between the philosophical and the theological model.

But the main and the most sensible point of the difference between the philosophical and the theological vitalism is

${ }^{4}$ Ibid., p. 15.

${ }^{5}$ Ibid., p. 12.

${ }^{6}$ Minucius Felix, Octavius, VIII, in the col. „P.S.B”, no. 3, Bucharest, EIBMBOR, 1981, p. 360. 
identified by Nietzsche in the Christian mercy, and we consider that he does it pretty ingeniously and relevant. Finally, the particular difference of the Christian humanism to the ancient one is the total mercy to peers, what made indeed the surprise and the absolute novelty of the Antiquity. In its rejection on ancient basis, Nietzsche invokes Aristotle", considering it an 'ill and dangerous disposition", because 'it opposes crossed, mostly and totally, to the evolution law ... it maintains what is baked for decay, it defends itself in the favor of the disinherited and sentenced of life, it exists through the great number of losers of any kind, whom he keeps alive ${ }^{\prime 9}$. If he is rigorous and not hypocrite, the theologian has to admit here that Nietzsche saw exceptionally; the interpretation of the phenomenon is, therefore, something else.

Most of the theologians appreciate Nietzsche's antiChristian attacks as being totally unreasonable, crazy and ill. We state that they are nothing but the clearest, the most grounded and convincing expression of the difference between the philosophical and theological vitalism. The philosophical vitalism opposes naturally and consistently to the theological one. As a proof we have Heidegger's conception according to which in the Christian Church 'a God has shaped for those comfortable and coward, a sort of life insurance 10 and, extremely significant, the one of the Christian philosopher N. Berdiaev, according to whom 'the opportunism of the Christian moral finds its supreme religious sanction in the mystics of submission ... the negative virtues - humility, disclaim, abstinence-shadowed the positive

${ }^{7}$ Aristotle, Poetica, 1449b, 26, Academics Publishing House, Bucharest, 1965, p. 60.

${ }^{8}$ Nietzsche, The Antichrist, cit.ed., p. 14.

${ }^{9}$ Ibid., p.13.

${ }^{10}$ Cf. Rudiger SAFRAnski, A master from Germany. Heidegger, Humanitas Publishing House, Bucharest, 2004, p. 268. 
virtues: manhood, nobility, honor' ${ }^{11}$. As it can be seen, the philosophical vitalism stays consistently antagonistic, in the whole history, to the theological vitalism.

\section{The answers of the christian theology}

Which can be the answer of the Christian theology to the complaints excellently stated by Nietzsche? Firstly, one must notice that there are a lot of grounds in order to argue the opposition of the Christian religion to the world, history and historical life in general. Christianity appeared, specified and imposed itself just through the opposition to the ancient conception about the world, history and life. We can state that the biblical formula 'Save yourselves from this wicked nation' (Apostles Acts 2,40 ) became the principle of life of the Christianity.

The first answer of the theology to the philosophic vitalism is that a rigorous and complete research brings, yet, a lot of Christian texts in the sense of treasuring the world and life. The Evangelist John says that 'For God so loved the world that He gave his one and only Son, that whoever believes in Him shall not perish but have eternal life'(John 3, 16) and Jesus Christ himself strongly underlined that He came 'that they may have life, and have it to the full'(John 10,10) that 'God did not send his Son into the world to condemn the world, but to save the world through him' (John 3,17). The condition of his apprentices is not the take out or separation but their observance in the world: 'My prayer is not that you take them out of the world but that you protect them from the evil one' (John 17, 15). Even the loneliest, monastic Christian tradition states that 'we did not teach ourselves to lock the wooden door but the door of our mouth'.

${ }^{11}$ N. Berdiaev, The sense of creation, Bucharest, Humanitas Publishing House, 1992, p. 233. 
The vitalist philosophers want to base their anti-Christian argument on the premise that any conception is authentic or vitalist if it assumes the world and life as given. The premise is indeed outright for any honest and rigorous thinker. But the question is, in fact, another one: what does 'taking life' mean? Which 'life' and which 'world'? A. Rimbaud says: 'La vraie vie est absente: nous ne sommes pas au monde'('The real life is absent: we are not in the world'). We often hear the expression: 'He loved life!'(as a merit of the dead) and we do not notice the ridicule of the praise. 'Which life' did the dead love, so as to be praised? The love of life as biology is nothing but the remaining in the animal kingdom, as all the animals love it and fight admirably for it. To take life and world means to take the absurd, ill and slipping into nothingness world, or to fight against this condition? In the whole problem of 'running from the world' and of Christian 'anti-vitalism', stating what is important in an issue and the solving consist of noticing the fact that in Christian theology the notion of 'world' has two meanings: 1.the entire creature, eternally positive and for the eternal life and 2.the degraded historical condition due to the sin. In the first sense, the Christian loves totally and eternally the world, and in the second sense he despises it and fights against it, to change it. He loves the world as you love the man, even if he is ill and ugly, and yet you hate the illness that disfigures him. Not the doctor that heals kindly loves the patient, but the one that treats him harshly and does not make a single concession to the illness, in order to be sure of the cure. To love the world and life as it is in the historical condition is not vitalism but ignorance, unconsciousness and morbidity, as it represents the cultivation of illness and death. The existentialist philosophy proved for good the historical condition of the world as absurd and nothingness.

To assume one's responsibility means both accepting and refusing. The responsibility to the world and life means refusing 
their degraded condition but assuming the existence in itself. Being the most aggressive conception against the ill condition of the world and life, the Christian faith combats it just from the conviction that change is possible, which is healing. The honest researcher must see that Christian theology does not look for solution in avoiding the world but in its change. It was not the Christianity the one that taught the escape from matter and world, but exactly the other philosophical or theological conceptions. Christianity is the only conception that maximizes the matter, world, history and man, as it sustains the final incarnation of God into matter, into world and into history. Only the Christianity affirms the transfiguration and the perpetuation of the matter and world, only he is by excellence 'the religion of the matter'. All the ancient conceptions considered matter, world and time a prison for the human soul, out of which only death can release. In Christianity, any spiritualization, any salvation and life is obtained only through valorization and perpetuation of matter and world. But this perpetuation is not a biological and mechanical one, but a removal of illness through fight, meaning through asceticism so nasty for the patient unconscious of his illness. Any victory and any Christian success cannot be obtained 'beyond', but it starts 'from here'. This new way of living is sacred and eternal not because it is 'beyond', but because it is 'different', obtained starting from here through what is called Christian holiness. The proof that only the Christian theology treasures and values this life and this world is the fact that it does not consider this life neither as a prison nor as an attempting or searching field, but one of full fight and gain starting from here. This obtaining is called 'the earnest' of the eternal life, and it is visible in the Christian holiness. It is to be observed that only the Christian faith offers and presents holiness in its own way, meaning experienced healing power. 
The Christian attitude towards the world, history and life is not the passivism but the activism. Not a single conception of the world states that it can totally change the world from here, as Christianity claims. The Christian religion tells the man that he can obtain the eternal life not because he follows certain commandments and rules, but because he fights for the life of the neighbor: 'Come and inherit the kingdom ... For I was hungry and you gave me something to eat...' (Mathew 25,35). The obsessive idea of the patristic theology is that 'from the neighbor comes both life and death' (Patericon, Abba Antonie, 11) or 'the hand of the poor that begs is Christ's hand'. In Christian belief salvation is neither knowledge, nor contemplation, nor quality, nor professional performance, nor accounting of good facts or virtues, but the promotion of the other's life or the success of the communion. Far from being avoidance, commodity or passivism, the Christian attitude to the world and life is the endless fight with the certainty of the victory. Christian is the one who 'soars in painful ascetic to overcome our depravity as creatures "as...we do not want to undress but to get dressed, in order to be swallowed what is mortal by life» (II Cor. 5,41). ${ }^{12}$

\section{Vitalism and optimism}

The philosophic vitalism considers faith in the afterlife as an escape to the present life, its despise and lack of appreciation, because it 'delays' the solving, that should be tried here. The philosopher has the duty to observe that the faith in the life that ends in nothingness is not faith in life but faith in nothingness: in nonsense. The treasure of life that leads to nothingness is actually absurd and impossible and cannot satisfy. If the experience imposes the absurd to man, anguish and death, his being opposes

12 Archim. Sofronie Sacharov, We will see God the way He is, Bucharest, Sophia Publishing House, 2005, p. 273. 
them entirely. It does not want to know but of sense and life. And this vital 'instinct' of man is not biological (as then all the animals would believe in eternal life) but it is the essential power of man, called theologically faith. But it is extremely important that we do not realize this faith unless we understand that it is not cowardice but courage.

To be noticed: those who believe in life believe in God. To accept God means to believe in the world and life, meaning in the eternally happy destiny, even if they are now deficient. In this respect, only religion can condemn explicitly and totally the suicide. Those who 'love life' (that ends in nothingness) actually dwell in illness, degradation, helplessness and nothingness, and aren't optimistic but the pessimistic on duty. They are tasters, funny, voluptuous and happy due to despair, they are the sybarites and hedonists that proclaim: 'Let's eat, drink and procreate, as tomorrow we will crack!' Pagan and philosophical vitalism seems more soared than the Christian one, as it is the soar of the severely ill man who, instead of following the severely curing treatment, prefers to frantically exhaust in 'living' the last moments. But his frenzy is morbid, as only patient's peace and 'passivism' that suffers quietly and confident the severe regime have the chance of curing.

There is only one authentic vitalism: the optimism. Or, 'optimism or pessimism of a person does not lie related to his state of being full or hungry, but with the number and quality of the worlds that can be perceived with his vision." 13 The philosophical vitalism is satisfied in the best of cases with the fight against evil (illness, sufferance and death), but admits that it has no chance to defeat it (as death and nothingness triumph) and, in this way, it does nothing but to proclaim the eternal victory of

13 Saint Nicholas VelimiROVICI, Teachings about right and wrong, Bucharest, Sophia Publishing House, 2006, p. 96. 
the absurd and nothingness. But the theological vitalism states that man's fight is real only because it has the chance of victory over death. In this respect, we may notice that deserters in front of life are the philosophical vitalists because, not having the chance of victory, they have nothing but to enjoy biologically, running from sufferance. If they were honest, they would admit that assuming sufferance without the chance of victory (as for example Camus and Sartre claim) is silly, awkward and ridiculous: the hedonist is here more logical and smarter than the stoic.

If the fully existence, the sense and human being's fulfillment consisted of earthly vitalism, than the supreme being is realized by the animals, eternally superior to man: as no man, however powerful and ambitious, will not develop a vital force and a longevity comparable to animals. Moreover: philosophy must admit that the philosophical achievement of the being opposes the 'vitalism'. That means: man is the superior being of the world and the pastor of the being, exactly by the fact that he is not a 'vitalist', that he refuses the existence as impersonal life and considers knowledge and being as change and sublimation of the historic condition. If man cannot change the historic condition, that means he is not Dasein and man does not exist. Without this sublimation philosophy does not exist as knowledge, and there is no philosophy, in fact.

One must understand that authentic vitalist is no one but the optimist and optimist is not the one who enjoys but the one who suffers, the one who assumes sufferance because he keeps unwavering the strength to believe in the sense of the world, of life and of being, above all the experiences of the absurd and death. The philosophical vitalism cannot be but the desperate soar of the hedonist and the theological vitalism non-Christian (pantheist: Buddhist, Hindus) is anti-human, because it pretends that satisfaction, happiness and supreme condition of man would 
be a passage into object and impersonal. The Christian thinking exposed long ago all these as being 'body carriers' 14 , apologists of the absurd, of death and nothingness.

\section{Vitalism and ostentation}

Pagan vitalism seems more powerful than the Christian one, and the philosophical more powerful than the theological. In paganism, people seemed to be bolder and stronger, being more visible and conspicuous. As a show, their deeds seem great, as they look like developing a greater freedom. It is to observe that man seems freer when he has no responsibility, and when he is responsible he does not seem free. Pagan vitalism did not make the man freer, nor more beautiful or better: 'they made people be possessed towards lust, celebrated as mysteries the crimes, deified the acts of mourning ... guided people to idols ... enchaining in the worst bondage with their mourning songs, that liberty truly beautiful of those who live under the sky'. ${ }^{15}$

Pagan and philosophical vitalism are indeed more spectacular than the theological or philosophical one, and that is why they seem more powerful. It is significant here that, symmetrically, evil is always more spectacular than good. Evil is fascinating because, being ostentatious, seems to be powerful, seems to impose itself. Here we want to remark that - as Heraclites and Heidegger notice - 'being likes hiding', and it is proper for good not to be ostentatious or spectacular but discrete and delicate, and also tenacious and efficient.

14 Saint Ignatius Antioch, Epistle to Smyrnaeans, chap. V, in col. „P.S.B.”, no. 1, Bucharest, EIBMBOR, 1979, p. 183.

15 Clement Alexandrine, Word of exhortation towards the Greeks (Protreptikos), chap. I, 3-1, in col. „P.S.B.”, no.4, Bucharest, EIBMBOR, 1982, p. 71. 


\section{Pagan and philosophical vitalism seems more powerful} than the Christian one as it is violent. Being unspectacular and unostentatious, Christian vitalism is less violent, even if in history one could see enough Christian violence: the great wars and especially the two world wars were provoked and maintained by the Christians.

The idea of the Christian vitalism 'emaciated' and drowsy (as it seemed for Nietzsche) is superficial. The fundamental Christian slogan was, from the beginning, that 'God did not give us the spirit of fear, but that of strength and love and wisdom' (II Tim. 1, 6-7) and that 'I can do all this through him who give me strength' (Philip. 4,13). But the Christian power is of other nature than the pagan or philosophical one. Christianity affirms that the nature of power is paradoxical. God Himself is 'absolutely «the great» but also forever "the small»' ${ }^{16}$, because no one can ever be as humble and go as down as His humble love can. Jesus Christ taught people that 'my power is made perfect in weakness' (II Cor. 12,9), that 'everyone who exalts himself will be humbled, and he who humbles himself will be exalted.'(Luke 18,14), and the understanding apprentice also claims with satisfaction:' for when I am weak, then am I strong' (II Cor. 12, 10). Non-Christians do not understand that power is paradoxical; God is great exactly because $\mathrm{He}$ is small: that means $\mathrm{He}$ is great and good because He can go down endlessly with His love. And $\mathrm{He}$ is strong, because $\mathrm{He}$ is weak, because $\mathrm{He}$ can behave childishly with His most modest creature, until accepting its rejection. Violence, ostentation or the spectacular are not strength but its surrogates, as craftiness is a surrogate of intelligence or the parasite a miming of being. The real power is represented by

${ }^{16}$ Arch. Sophronius SACHAROV, Birth to unrinsed kingdom, Alba Iulia, Editura Reintregirea, 2003, p. 229. 
love, humbleness, patience and endless waiting, which never give in.

Modesty does not mean lack of power. However modest, the Christian is by definition a fighter. The strongest athletes of all times were not the philosophers or the ancients, but the athletes of faith and especially the Christian martyrs and monks. In 'Patericon', Abba Pimen says 'Where there is fight, there am I!' ${ }^{17}$, and amma Sinclitichia throws the glove, provoking the fight: 'More the athletes progress, more they hit themselves of a more powerful adversary'18. Christianity is the most powerful fighter, because it is the only one convinced to be the bearer of God's power. All the Christian martyrs had the slogan: 'In the martyr does Christ fight!', and the Christian monks fight only through the conviction that the end means deification, which is achieving the divine condition.

But even accepting the Christian vitalism as power, the philosophers and pagans reject it, on the ground that it is 'emaciated', that it represents more like an irrational force and a poor and severe vitality, until becoming gloomy and sad. These are to be reminded the biblical texts in which the Christian vitalism explodes out of its force, abundance and happiness. Jesus Christ pretends to His followers: 'Take heart! I have overcome the world!' (John 16, 33) and He promises that 'I have come that they may have life, and have it to the full' (John 10, 10). He accepts the charge of His enemies that $\mathrm{He}$ is a 'glutton and a drunkard, a friend of tax collectors and sinners' (Mathew 11, 19). Father Nicholas Steinhardt observed exceptionally that Jesus Christ was a 'gentleman', a generous that has never escaped the

${ }^{17}$ The Egyptian Patericon, Abba Pimen, 202, Bădiliță edition, p. 300.

${ }^{18}$ The Egyptian Patericon, amma Singlitichia, 14, Alba Iulia edition, p. 227; Bădiliță edition, p. 352. 
opportunity of a feast with the people, because He loved them ${ }^{19}$. A definite proof of the generosity, spill and abundance of the Christian vitalism is exactly the image of the eternal life offered by Jesus Christ as a feast: 'So that you may sit at My table, eat and drink at My table, in My kingdom' (Luke 22,30). The Christian vitalism is neither dry spiritualism, but nor mere biology. The supreme joy is neither howl nor ha-ha. The Christian vitalism is abundance and sober joy, because being and life themselves are generosity and seriousness in the same time. So, one can understand that vitalism and joy are supreme in the daily greeting, serious but overflowing, of Saint Seraphim of Sarov: 'My joy, Christ has resurrected!'. The Christian principle is the following: 'A sad saint would be a sorry saint!'. The saint is not sad, nor frightened, but sober and delicate. The most powerful joy is the sober one. Otherwise, it is significant here also the fact that - with the exception of the vitalist philosophers - the specialists admitted not only the force and authenticity but also the richness, optimism, delicacy, overflowing and incomparable generosity of the Christian vitalism.

\section{Pagan heroism (philosophical) and christian heroism (theological)}

The difference between the philosophical vitalism and the theological one has materialized at its maximum in the difference between the philosophical heroism (or pagan) and the theological heroism (or Christian).

In any philosophy and in any theology, the supreme human involves essentially the heroism. Even if it is understood and presented in very different forms, the fulfillment of man is a heroic condition. Very special among these is the heroism and

19 Nicolae STEINHARDT, Giving you shall receive, ('Writings', vol. II), Publishing House of Rohia Monastery, 2006, p. 31. 
the Greek hero. He was preserved not only in the myths of the Greek theology but also in the Greek tragedies. If the myths present only the attitude of the hero, the tragedies also present his thinking. The deepness of ideas and the hero's audacity make the Greek tragedy the peak of the Greek spirituality an imperishable proof of the human genius and greatness. To avoid, to ignore, to despise or to condemn the Greek heroism would be an obtuseness or an unforgivable superficiality. Any researcher on the issue of heroism must begin from the greatness of tragedy and Greek hero. However convinced of the superiority of the Christian heroism, the theologian has to know that he has the chance to reach the truth not by avoiding or minimizing the Greek heroism but through its possible overcome. In fact, the relationship of the Christian heroism with the Greek one is similar to the one between faith and reason, between theology and culture or theology and philosophy. Faith and theology are authentic not by denying or fighting the reason and philosophy but by collaboration and the possible passage into a superior condition. The man is great not only when he fights building the sense and being but also when he fights against the absurd and nothingness: as this is the condition of the Greek tragedy and hero. The Greek hero is great because he defies and faces the destiny, divinity and being. But the question remains: is there, by any chance, facing the being the supreme heroism? Is there the passage from the Greek heroism to the Christian one a domestication, training or an incarceration of the splendid unchained being, now brought into the cage? Is the Christian mercy an incarceration, a weakness, a training or a distortion of the human vitality?

However, there is no wonder that in the history of civilization and philosophy it has constantly endured the unconditioned admiration to the Greek tragedy and hero. Adding to this the oblivion and distortion of the Christian faith, one can understand how some people came to believe in the superiority of 
the Greek and philosophical heroism to the Christian or theological one. As man against God seems more powerful, greater, more valuable and more impressive than the man reconciled with God, as the Christian hero is. This seems deprived of value and fun: the tragedy seems to have become drama and the heroism platitude.

One must notice that essential and specific for the Greek heroism are two dimensions: 1. the spectacular, 2. the despair. The Greek heroism is necessarily spectacular. The Greek hero must do something 'memorable' and despise the gods, as Homer (Iliad XXII, 305) and Alexander the Great say. The Greek is a hero if he succeeds a great show and if he imposes in the world and history. He must as well defy the gods. As we know, the Greek theatre did not know the drama; so, if he does not defy the gods the Greek hero is not great anymore but decays, and the tragedy becomes comedy. Secondly, it is to be observed that tragedy and the Greek hero's greatness consisted of his despair, in the fact that he faces without any chance the being, the destiny and the divinity. To these essential dimensions of the Greek heroism, it is firstly imposed the observation that being and good are not show, are not something 'memorable'. Good is not show, the being is not show also and it is not 'memorable': it exists and resists. The philosophy must observe that the being and the good are more silence than word, that being (Heraclites and Heidegger's saying) 'likes more to hide'. Secondly, however tragic the world would be, history and human condition, as much absurd and nothingness would experiment and face, man cannot live through absurd and despair, even if Shakespeare says that 'from my despair a better world is born' and V. Voiculescu that 'despair was my light all the time' and Divinity is 'the supreme despair/ with an averse universe turning around him' (The last sonnets, 70). There is a greatness of despair, but the man cannot canton in it and, in any case, it cannot be the supreme vitalism. 
With this we actually reach the dispute between the philosophy and theology reaching the suicide. From the philosophical point of view suicide can be the supreme heroism, whereas from the theological point of view it is cowardice, as the supreme courage is not to face death but to face life, with its endless sufferings.

\section{The specific of the christian heroism}

But how does the Christian heroism look like and what is its specific, to the ancient or philosophical one? The nonChristian theological heroisms are either insensitivity and passivism (Buddhism), or the biological vitalism (Hinduism), or the aggressive missionary (Islam). To them, the most significant and efficient Christian reporting is the one to the Greek heroism, because this one is similar to the philosophical one.

To the Greek and philosophical heroism, one reproaches to the Christian heroism the humiliation, the indulgence and the submission, as being non-combatant, non-heroic, and contrary to life. The Christian theology answers here that there is a single unbridled hero that, humble, loving and submitted, resisted endlessly, did not defy and did not despair, believed in being and succeeded: Jesus Christ. The examples of the fighting up beyond the white sails Christian heroism are endless. The adversaries of the Christian faith always accused it that it is a 'religion of the slaves', of silly ones, of those ill and weak. Indeed, it is essential to understand that, far from dishonoring it, all these ratings constitute the honor, force and incomparable beauty of the Christianity as heroism. One must not forget that, just through these 'weaknesses', Christian faith is the unique force that destroyed the absolute state (the Roman state), domesticated the human and put the basis of the modern civilization. Any martyrdom is heroism, but the Christian martyrdom along the history does not suffer any comparison. We do not enumerate the 
various cases of the Christian martyrs that did not yield not even in front of the sufferings of the dearest ones (as the couple Timothy and Maura, crucified for 9 days, face to face), but we remind only the case of a humble nun, that 'has been in a terrible fight, for thirteen years, with the demon of fornication and has never prayed to be spared of the war but she always said: «God, give me strength!» ${ }^{20}$.

If the Greek hero is necessarily vainglorious and proud, the Christian hero is humble and even silent. The Greek and philosophical hero is conscious and explicit in his heroism: the Christian hero assigns his patience and victory to Christ; if he believed that it is due to him, he would not be a hero anymore. It is a situation similar to the relation between genius and saint: the genius is conscious and explicit of his genius, the saint is implicit and not explicit. This was noticed excellently by Heidegger's friend, Paul Tillich, who remarked that 'the truth regarding the vitalist interpretation of the ethics is the grace. The courage as grace is a result and a question ${ }^{21}$.

Above the vainglory or humility, the difference consists of the fact that Greek heroism is essentially distrust, despise and even hate to being and Divinity. In contrast to him, the Christian heroism is motivated by trust in human being and God. If the maximum of the Greek heroism is stoicism, contempt and hate, the maximum of the Christian one is trust, love and joy. The suffering is the distinctive criterion between the Greek heroism and the Christian one (between philosophy and theology), because the first one does not solve it at least logically, much less factually, whereas the Christian one reaches optimism and joy. In

${ }^{20}$ The Egyptian Patericon, amma Sara, 1, Alba Iulia edition, p. 224; Bădiliță edition, p. 348

${ }^{21}$ Paul Tillich, The courage of being, Herald Publishing House, Bucharest, 2007, p.102. 
Christianity, suffering necessarily leads to optimism, victory and joy.

But the most concrete point, the central distinguishing point and the Gordian knot that knots and unknots the entire issue of heroism is the mercy. Nietzsche excellently intuited it. He understood that Christian faith is 'the opposite of any fight ... the inability to resist ("do not resist against evil») ... the impossibility to have enemies ${ }^{22}$, that the essence and the specific of the Christian faith is the mercy. He saw something, but he misinterpreted it. Nietzsche considers mercy as being reprehensible, because 'it opposes to tonic affects that increase the energy of the life feeling; it acts depressively. The human loses power when he has mercy ... due to mercy one can reach the total loss of life and energy for life... ${ }^{23}$. If mercy is weakness and anti-life, Nietzsche considers that the solution is 'to be doctors, to be ruthless, to handle the scalpel... this is our way to love people... ${ }^{24}$. It is interesting that even the great poet R.M. Rilke - mystical in his adulthood - was seeing and expecting in his youth a solving similar to Nietzsche: 'Messiah made out of the whole world a hospital... how can we give our strength to bastards, oppressed, worthless idlers, lacking any sense and energy? Let them fall, collapse, die, alone and miserable. Be rough, be terrible, be merciless! You must advance, advance. Few people, but great ... will raise a world with their strong arms... ${ }^{25}$ Nietzsche and Rilke's argue is indeed excellent from the polemical and artistic point of view, but disastrous philosophically and theologically.

${ }^{22}$ Fr. Nietzsche, The Antichrist, cit.ed., p. 41.

23 Ibid., p. 13.

24 Ibid., p. 14.

25 R.M. Rilke, The Apostles (short story, 1896), cited Henri de Lubac, 'The drama of the atheist humanism', Humanitas Publishing House, Bucharest, 2007, p. 101. 
Anti-Christian vitalists charge Christianity of anti-vitalism, due to the move of the interest from the powerful ones towards the weak, inferior and useless ones. But the problem is right here: if the Greek and philosophical heroism is exclusive and elitist, the Christian heroism is inclusive and counts on the weak ones, because it trusts the whole being, not being able to conceive any loss, of any kind. The Greek and philosophic heroism operates with the Spartan selection and elimination, just because they do not trust in the being, cannot believe that the being is sovereign, sufficient and able to solve. To believe that the being is contradictory in itself - as the Greeks and philosophers do - is the same with not believing in it. The Christian heroism fights for the weak and 'irresolvable', because for him 'irresolvable' does not exist. He is considering the concrete human too not only the species, because humanity composes itself not from a selected flock or sum, but from unique people and unrepeatable values. The conception about man as person separates the philosophical heroism from the theological one.

The philosophical heroism believes that mercy means distrust, because it does not leave the other to handle by himself. But incredulous is philosophical heroism, because it abandons some of them out of principle, whereas the Christian heroism starts as a principle from the idea that all are savable, that anytime from minimum one can get the maximum, from illness health and from death life; the Greek and philosophical heroism have no idea of these. If the Greek heroism counts on life, health and power, the Christian heroism counts on weakness, illness and sufferance, just because it considers them solvable. It is true that mercy is the expression of faith and not reason: that is why it remains the distinguishing criterion between the philosophical and theological heroism.

The essential issue is to understand that mercy is not weakness but strength. As the Greek and philosophic heroism is 
the heroism at a certain moment, whereas mercy is the every moment heroism, hour by hour, day by day, of a lifetime, the infinite heroism, daily martyrdom or the white blood. It is much easier to be a hero at a certain moment, hero for a moment, than hero for a lifetime. To have mercy means not only to assume the other, but even to become the other, means to assume the wholeness of the being. If the Dasein is place and shepherd of the being, then it is the one who assumes the wholeness of the being; otherwise, its relation with the being is unessential and inauthentic.

\section{Heroism and asceticism}

In fact, the mercy to others means the fight with your own selfishness, meaning the fight with itself or the asceticism. The pagan or philosophical hero believes that by defying and denying divinity and the being he reaches freedom. Or, freedom cannot be but affirmation and not denial. The ancient heroism invites us as the nihilist or existentialist philosopher - to absurd, despair and suicide. Or, freedom cannot exist than if it is possible affirmation and construction, not the denial of the being. There is only one freedom of man: self-control, sovereignty upon itself, through the victory over irrational starts, meaning over passions. However great and soared would appear the pagan and philosophical hero, the scale of his fight is nothing but the scale of his passions and self-demolition.

A single fight is constructive: the fight with the self, patience or asceticism. The pagan and philosophical hero knows nothing about the fight with the self, but with the others. Even if he practices asceticism, as the stoics, this is a simple ambition that is also passion - that has nothing to do with the Christian asceticism, even if Heidegger understood that 'abstinence does not damage' ('Verzicht nimmt nicht!'). For the pagan or 
philosophical hero, selfishness and pride remain the supreme power and achievement; for the Christian one these are his maximum sin and weakness.

To take note of being means in the first case to be aware that abnormality or its declined state is due to the person and, so, the person can also make it right, through its own straightening. The being is ill because the person got ill. But it cannot get ill than what was once healthy; so, there is also healing. Being a hero does not mean to distrust or despise the being, but to love it and to trust it. Here Heidegger should recall the words of his favorite poet, Hölderlin: 'That who thinks deeper, loves livelier $^{26}$.

Anti-Christian vitalists believe that asceticism in general (and asceticism in particular) is irrational and kills life. They do not know the Christian conception about man's affects and passions. The Christian theology considers man's affects as rational or even more as being of a divine reason. But these affects can be directed by man's will, according to nature or against nature. When they are auctioned against nature, they become passions. They are nothing but the rational that can dominate and kill man: 'Thus passions are a movement of the soul against nature ${ }^{27}$. The Christian conception regarding the passions materialized itself in asceticism. From the severity with which Christian asceticism was shown, the vitalists concluded its irrationality. Indeed, in the Christian documents there are mentioned cases of a very severe asceticism, as the hermit that mortifies his body with the reason: 'I kill it (the body, n.n.), so that it cannot kill me!'(Patericon). One must know nonetheless

${ }^{26}$ See Fr. HöLDERLIN, Socrates and Alcibiades: 'Wer das Tiefste denkt, liebt das Lebendigste'.

27 John BeHR, Christ's sacrament, Bucharest, Sophia Publishing house, 2008, p. 203. 
that, regardless the degree of severity, the idea of the Christian asceticism is always the same: self-control and mastery of the body, not its killing. A wonderful proof of the Christian asceticism is shown by one of its severest practitioners, Saint Antonius the Great, who at its end 'was looking as they knew him even before the withdrawal ... Not locked in himself, due to abstinence, not pouring himself from pleasure, not mastered by laughter, not overcome with sadness... But he was totally equal to himself, as one who was led by logos and settled in what is good for nature 28 .

The purpose and the end of the Christian asceticism is not weakness and death, but the supreme power and the full life. The Christian asceticism is not the mortification of the body but the mortification of the passions ${ }^{29}$. It is neither insensitiveness (like in Buddhism) but maximum sensitiveness and delicacy, nor mystical performance, as in Islam or Buddhism.

If the pagan and philosophical heroism teaches us the art of dying, asceticism as Christian heroism teaches us the art of revival. As by turning the passions towards the rational direction, it heals and sanctifies man. Proper and rational to man is not only the natural health (as man is not just nature) but the total health or the holiness, which means 'to keep the incorporeal inside the body ${ }^{30}$. Through asceticism, man's passions are not canceled but changed. The Christian ascetics do not become and are not asexual, but full, as Saint Simeon the New Theologian shows in his 'Hymns'.

28 Saint Athanasius the GReat, Life of Saint Antonius, 14, in 'Writings', II, col. „P.S.B.”, no. 16, Bucharest, EIBMBOR, 1988, p. 201.

${ }^{29}$ The Egyptian Patericon, abba Pimen, 184, Alba Iulia edition, p.190: 'We did not learn to kill our bodies, but our passions'; see also Bădiliță edition, p. 298.

30 Saint John Climacus, The Scale, 27, in 'Philokalia', 9, Bucharest, 1980, p. 380. 
The health and force pursued by asceticism are not an imagination or a state of questionable bliss, but a visible power in man: 'As body is honored, in the moment of His reception, and the Godhead glory becomes the body's glory'31. So powerful, so visible and sovereign is the new condition obtained through asceticism, that about one of these conquerors the documents tell us that, in his entire poverty and simplicity, he looked 'as an emperor on his throne, 32 and 'one could not watch his face due to the glory he had'33. The Christian asceticism and heroism are neither performing, nor flashy but organic.

\section{Asceticism, as re-credibility of the christianity}

Undoubtedly, the human authentic and supreme materialize in heroism. A vitalism without heroism is mere biology. If we want to reach the full relation between the pagan heroism and the Christian one, it is very important to notice that all the antiChristian contestations had grounds, that they did not contest the Christian heroism in principio but in facto. They admired without reservations the heroism of the primary Christianity and blamed not the Christian heroism, but the Christianity without heroism or the Christians without Christianity. Faith in general and the Christian faith in particular is authentic only to the extent in which it is heroic. In the way in which Christianity insists on denials and not on affirmations - the denial of the world, body, life, history or fight, as resignation and sadness - it distorts itself and it is no longer Christianity. To the extent in which they found that the world and the Christian Church remain definitely inferior

${ }^{31}$ Hagiorite Tome, For those who dwell sacredly, in 'Philokalia', vol. 7, Bucharest, EIBMBOR, 1977, p. 418.

32 The Egyptian Patericon, abba Pambo, 2, Alba Iulia edition, p. 190; Bădiliță edition, 12, p. 304.

${ }^{33}$ Ibid, 1, p.190; Bădiliță edition, 1, p. 301. 
to ancient pagan heroism, Nietzsche and Heidegger are right. They are neither superficial nor infidels, when they admire the pagan heroism and despise the historic evolution of the Christian idea. The gloomy piety, the dark churches and monasteries as some 'God's crypts and tombstones ${ }^{34}$, remain proofs in the rightness of these observations. It is conspicuous the fact that Heidegger admired in the same way the pagan heroism and the primary-Christian one, and Nietzsche stated: 'Essentially there was a single Christian, and He died on the cross! 35 . It is obvious that, from the primary Christian till today, Christianity has sweetened towards the good life, modernized itself, declined from being into beingness and lost a lot from the heroic condition. It can become credible only through asceticism and mercy, as daily heroism or 'the white blood', as even challengers like Heidegger and Camus have expected ${ }^{36}$.

1.But this is only the truth or the visible face of the Christian Church. The one who has the patience to deeply research will see that in it there are still active mercy and asceticism, because they can be concretely and supremely experienced in the Christian holiness, inconspicuous and silent, that still sustains the world, life and being.

${ }^{34}$ Fr. Nietzsche, The cheerful science ('Die fröhliche Wissenschaft'), III, 125, Humanitas Publishing House, Bucharest, 1994, p. 131.

${ }^{35}$ Fr. Nietzsche, The Antichrist, 39, cit.ed., p. 52.

${ }^{36}$ A. Camus, interview, in 'Revue de Caire', 1948: 'As for the Church, I will take it into serious only when the spiritual leaders will speak as everyone and will live themselves the dangerous and rough life that the many lead'. 